\title{
The Effects of the Peer Feedback Process on Reviewers' Own Writing
}

\author{
Reina Wakabayashi ${ }^{1}$ \\ ${ }^{1}$ Faculty of Foreign Language, Dokkyo University, Japan \\ Correspondence: Reina Wakabayashi, Faculty of Foreign Language, Dokkyo University, 1-1, Gakuencho, Soka, \\ Saitama 340-0042, Japan. Tel: 81-48-946-1813. E-mail: wreina@dokkyo.ac.jp
}

\author{
Received: May 24, 2013 Accepted: June 7, 2013 Online Published: August 15, 2013 \\ doi:10.5539/elt.v6n9p177 URL: http://dx.doi.org/10.5539/elt.v6n9p177
}

\begin{abstract}
The purpose of this study is to determine which is more beneficial to improving learner writing: reviewing peer texts or one's own text. The study took place over one semester at a Japanese university with 51 students enrolled in two writing classes at two proficiency levels. The students at the lower proficiency level reviewed peer texts, while those at the higher proficiency level reviewed their own texts. Multiple task sheets were used in both classes for students to give detailed feedback on texts. To examine gains in writing quality, a comparative analysis was conducted on writing samples collected at the beginning and the end of the semester. A questionnaire survey was also conducted to investigate the students' perceptions towards the tasks. The results of the analysis indicated that the students who focused on reviewing their own texts made more total gains in score than did the students who focused on reviewing peer texts. On the other hand, a significant correlation was observed between score gains and perceived effectiveness of the task with the students who focused on reviewing peer texts. The pedagogical implications of the results are discussed.
\end{abstract}

Keywords: peer feedback, reviewer, writing quality, learner perception

\section{Introduction}

As the process approach (Mittan, 1989; Zamel, 1985) has become a major orientation of pedagogy in both first and second language writing classrooms, peer feedback has come to take an important part in writing instruction. Given the definition of feedback as "input from a reader to a writer with the effect of providing information to the writer for revision (Keh, 1990, p. 294)," peer feedback is primarily a variety of input that is given from one learner to another. In a writing classroom, however, peer feedback is more than merely a type of feedback but the dynamic process of reviewing peer texts and negotiating as both reviewer and writer. Through peer feedback, learners engage in critical evaluation of peer texts for the purpose of exchanging help for revision. The rationale of this process is explained by the framework of sociocultural theory. Vygotsky's $(1978,1986,1987)$ notion of Zone of Proximal Development (ZPD) is a theoretical concept based on sociocultural theory. This theory, which originally dealt with child cognitive development, explains that cognitive development occurs as a result of social interaction in which an individual learns through the guidance of more experienced others. The ZPD refers to the distance between one's actual developmental level and the potential developmental level. The supportive interaction was also termed as scaffolding (Wood, Bruner, \& Ross, 1976) and occurs between novice learners as collective scaffolding (Anton \& DiCamilla, 1998; DiCamilla \& Anton, 1997; De Guerrero \& Villamil, 2000; Donato, 1994). By applying sociocultural theory as a basis, interaction is by definition a crucial component of peer feedback.

In the interactive process of peer feedback, learners play a dual role of writer and reviewer, and thus learners should expect benefits associated with both roles. Nevertheless, research to date has focused primarily on the benefits for writers, including the positive effects of peer feedback on writing quality (Berg, 1999; Hedgcock \& Lefkowitz, 1992; Paulus, 1999; Villamil \& De Guerrero, 1998), the behavior of incorporating peer comments in revision (Connor \& Asenavage, 1994; Mendonça \& Johnson, 1994; Nelson \& Murphy, 1993), and the enhanced sense of audience and ownership of text (Carson \& Nelson, 1994; Mangelsdorf, 1992; Tsui \& Ng, 2000). The major advantage of taking a reviewer's role appears to be the development of critical evaluation skills and the subsequent development of self-revision skills (Rollinson, 2005), but empirical research remains scant in this area.

Among studies that have focused on the reviewer's stance in peer feedback (Lundstorm \& Baker, 2009; Min, 
2005; 2008; Tsui \& Ng, 2000), Tsui and Ng (2000) discovered that learners learned more about writing by reviewing peer texts than by receiving peer comments. Min (2005) examined the effects of training on peer feedback and reported that learners improved their skills in providing peer comments on global aspects of writing (i.e., development and organization) through modeling and one-on-one conferencing with their teacher. Having a focus on global aspects of writing is a trait associated with skilled writers (Raimes, 1985; Zamel, 1983). Moreover, Min (2008) investigated the effects of training on style of interaction during the peer feedback process. She reported that learners took a more collaborative stance after training. This was found to be the most effective stance to take in meaningful peer feedback sessions (Lockhart \& Ng, 1995a, 1995b; Mangelsdorf \& Schlumberger, 1992). Tsui and Ng (2000) suggest that reviewing peer texts is at the core of peer feedback, and Min's research $(2005 ; 2008)$ indicates the significance of training in improving these skills. However, research that directly examines the effects of reviewing peer texts remains lacking.

Lundstorm and Baker's (2009) study was remarkable in that it presented virtually the first qualitative research on the benefits of peer feedback focusing on the act of reviewing peer writing. However, a limitation of the study was that the procedure had the participants engage in peer feedback activities using sample essays, not their own authentic texts. The rationale of using sample essays was explained as a way to ensure that the participants worked on essays of the same quality, yet this treatment likely affected the participants' behaviors. That is, providing peer comments for or revising sample essays that were not written by peer students in the classroom was probably difficult, especially in regard to the global aspects of writing, because the participants did not have a sense of ownership or a real audience. Moreover, the task format lacked several necessary factors referred to in the study that are involved in real-life peer feedback. As shown in Table 1, learners who engage in peer feedback in a real setting have access to roughly four kinds of cognitive activities or sources of information for revision: reviewing peer texts, utilizing peer comments, negotiating in peer discussion, and providing self-feedback, including processing ideas that arise through peer feedback.

Table 1. Cognitive activities involved in revision with and without peer feedback

\begin{tabular}{ll}
\hline With peer feedback & Without peer feedback \\
\hline Reviewing peer texts & - \\
Utilizing peer comments & - \\
Negotiating in peer discussion & - \\
Providing self-feedback & Providing self-feedback \\
\hline
\end{tabular}

As the term suggests, peer is a crucial concept in peer feedback. Lundstorm and Baker (2009) compared the impacts of reviewing texts and utilizing comments on writing quality without peer, so to say. In the present study, the effects of two cognitive activities of reviewing peer texts and providing self-feedback on writing quality are examined since self-feedback forms an inevitable cognitive activity involved when revising text. As Ferris (2003) pointed out, "the mere act of rereading and rewriting, even without feedback from peers or teacher, may lead not only to substantive changes but improved writing quality" (p. 82). The question here is, do learners need to engage in peer feedback if rereading and rewriting texts alone is sufficient to improve writing quality? If reviewing peer texts would bring more gains in writing quality than reviewing one's own texts, the results would suggest the significance of reviewing peer texts; if the opposite were the case, the results would suggest that the task of reviewing peer texts does not entail a more effective form of learning compared to reviewing one's own texts. Moreover, the results could also indicate that other cognitive activities, such as peer negotiation or utilization of peer comments, are indeed significant activities in peer feedback. Note here that this study is distinguished from studies that compared the effects of self-feedback and peer feedback on revision (Connor \& Asenavage, 1994; Diab, 2010a, 2010b, 2011; Nakanishi, 2008) as their interest was rather in utilizing peer or self-comments.

To focus on the reviewer's role, the dual role of a learner needs to be defined in the definition of peer feedback. In their comprehensive book on peer feedback, Liu and Hansen (2005) define peer feedback as:

The use of learners as sources of information and interactants for each other in such a way that learners assume roles and responsibilities normally taken on by a formally trained teacher, tutor, or editor in commenting on and critiquing each other's drafts in both written and oral formats in the process of writing. (p.1)

This definition is problematic as it specifies learners' roles as those "normally taken on by a formally trained 
teacher, tutor, or editor," which is not realistic, especially for learners at low proficiency levels. Moreover, in peer feedback, learners should not be expected to take over the role of the teacher or anyone in the position of teaching. Instead, learners are agents in peer feedback, which provides the ground upon which learners scaffold each other's learning. Scaffolding (Wood, Bruner, \& Ross, 1976), a concept based on a sociocultural view of learning, can also be used to characterize collaborative learning (Bruffee, 1984). In the present study, peer feedback is defined as a collaborative learning task by which learners acquire revision procedures while taking on the dual role of writer and reviewer. While peer feedback research has placed more attention on the writer's role than on the reviewer's, this study will address the following questions:

1. Do students who review peer texts improve their writing quality more than those who only review their own texts?

2. How do students perceive two types of feedback task (reviewing peer texts without exchanging comments and reviewing only one's own text) compared with a standard type of peer feedback task (review peer texts with comment exchange and oral negotiation)?

\section{Method}

\subsection{Participants}

Fifty-five students at a Japanese university participated in the study. They were all first-year law students enrolled in the author's two writing courses in the fall semester of 2012. Course admittance was based on TOEIC IP ${ }^{\circledR}$ placement test scores, which placed 27 participants in a low-intermediate level class (scores from 300 to 400 ) and 24 students in a high-intermediate level class (scores above 400). The classes were taught using the same textbook (Hogue, 2008) on the same course plan. The students in both classes had written three paragraphs on the same topics in the previous semester. In the fall semester, a standard type of peer feedback was given to the first drafts, and teacher feedback was given to the second drafts in conferencing sessions. A standard type of peer feedback here refers to a standardized peer feedback procedure by which learners exchange their texts to read and provide both written and verbal peer comments.

\subsection{Class Procedure}

A 90-minute class met once a week for 15 weeks. Students wrote four paragraphs on different topics (See Appendix A). Each paragraph was written over three weeks. Figures 1 and 2 summarize the writing process of a paragraph in class 1 and class 2 , respectively.

\begin{tabular}{|c|}
\hline Week 1 \\
\hline In-class: \\
\hline Brainstorming and planning \\
\hline Assignment: \\
\hline Submit outline via LMS \\
\hline
\end{tabular}

\begin{tabular}{|l|}
\hline Week 2 \\
\hline In-class: \\
1. Feedback on peers' \\
outlines \\
2. Revise one's own outline \\
\hline Assignment: \\
Submit revised outline and a \\
first draft via LMS \\
\hline
\end{tabular}

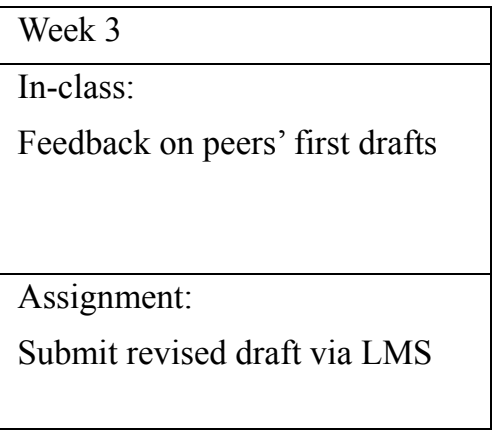

Figure 1. Writing process of a paragraph in class 1

\begin{tabular}{|l|}
\hline Week 1 \\
\hline In-class: \\
Brainstorming and planning \\
\hline Assignment: \\
Submit outline via LMS \\
\hline
\end{tabular}

\begin{tabular}{|l|}
\hline Week 2 \\
\hline In-class: \\
1. Feedback on one's own \\
outline \\
2. Revise one's own outline \\
\hline Assignment: \\
Submit revised outline and a \\
first draft via LMS \\
\hline
\end{tabular}

\begin{tabular}{|l|}
\hline Week 3 \\
\hline $\begin{array}{l}\text { In-class: } \\
\text { Feedback on ones' own first } \\
\text { draft }\end{array}$ \\
\hline $\begin{array}{l}\text { Assignment: } \\
\text { Submit revised draft via LMS }\end{array}$ \\
\hline
\end{tabular}

Figure 2. Writing process of a paragraph in class 2 
The major difference between the writing processes of class 1 and class 2 was that students in class 1 reviewed peer texts, while those in class 2 reviewed their own texts. In class 1, peer feedback tasks were constructed in a way that students reviewed peer texts without exchanging peer comments. Students in both classes reviewed texts using feedback task sheets prepared by the teacher. In the first week, the students in both classes engaged in discussion in pairs or groups of three as a brainstorming task on a writing topic. The students then started composing outlines in class. The students finished making the outlines as a homework assignment and submitted them online via a learning management system (LMS). The teacher made copies of the outlines for use in feedback tasks in the following week. In the second week, the students in class 1 each reviewed an outline written by a classmate using a task sheet (see Appendix B). After the teacher collected the peer outlines and task sheets, the students revised their own outlines in class and started composing first drafts. The students finished composing the first drafts as a homework assignment and submitted them via LMS.

Class 2 in the second week followed basically the same instructions as those for class 1 except that the students reviewed only their own texts. The students in class 2 reviewed their own outlines using the same task sheet as that used in class 1 with necessary changes in wording (see Appendix C). After the teacher collected the outlines and task sheets, the students revised the outlines and started composing first drafts. As in class 1, the students finished writing the first drafts as a homework assignment and submitted them via LMS.

In the third week, the students in class 1 reviewed the first drafts written by three classmates. The three peer texts were reviewed using three different task sheets that each focused on organization, content, and "grammar and mechanics." The peer texts and the task sheets were collected after the class. The students revised their own first drafts as a homework assignment and submitted them as final drafts via LMS. The students in class 2 reviewed their own first drafts in the third week using the three kinds of task sheets used in class 2 with different wording as required. As in class 1, the texts and task sheets were collected after class. The students revised their own first drafts as a homework assignment and submitted them as final drafts via LMS.

Since the focus of the study was to investigate the effects of reviewing peer texts, not that of receiving peer comments, all the reviewed texts and task sheets were collected after class so that the students in class 1 would not exchange their comments for use during the subsequent revision process. To equalize the condition, the texts and task sheets in class 2 were also collected so that the students could not refer to the self-feedback comments in revision.

\subsection{Data Collection}

As pre- and post-tests, students wrote a 20-minute timed essay by hand at the beginning and end of the semester. Writing topics for TOEFL iBT ${ }^{\circledR}$ independent essays were used as prompts. There were two prompts for the pre-test from which the students could choose one: Do you agree or disagree with the following statement? People should sometimes do things that they do not enjoy doing. Use specific reasons and examples to support your answer; some universities require students to take classes in many subjects. Other universities require students to specialize in one subject. Which is better? Use specific reasons and examples to support your answer. There were also two prompts for the post-test from which the students could choose one: Should governments spend more money on improving roads and highways, or should governments spend more money on improving public transportation (buses, trains, subways)? Why? Use specific reasons and details to develop your answer; some people say that advertising encourages us to buy things we really do not need. Others say that advertisements tell us about new products that may improve our lives. Which viewpoints do you agree with? Use specific reasons and examples to support your answer. The essays were rated by two raters. Both were native English speakers who had had 10 years of experience teaching English at the university level in Japan. The raters gave scores to anonymous student essays using the ESL Composition Profile (Jacobs et al., 1981) as a rating rubric. The rubric was comprised of five aspects of writing: content (13-30 points), organization (7-20 points), vocabulary (7-20 points), language use (5-25 points), and mechanics (2-5 points).

A questionnaire survey was conducted at the end of the semester, on the same day as the post-test essays were written, to investigate the students' perceptions of the feedback tasks compared with those conducted in the previous semester. The questionnaire, which was written in Japanese, included the following 11 questions (translation is mine): Q1. Was the feedback task in the fall semester useful in revising your texts? Q2. Was the feedback task in the fall semester useful for learning about writing? Q3. Is reading peer texts effective in learning to write? Q4. Is providing written peer comments effective in learning to write? Q5. Is providing oral peer comments effective in learning to write? Q6. Is receiving written peer comments effective in learning to write? Q7. Is receiving oral peer comments effective in learning to write? Q8. Which was more effective for you, the peer feedback task in the spring semester or the feedback task in the fall semester? Q9. What were the 
advantages of the feedback task in the fall semester? Q10. Were there any difficulties in working on the feedback task in the fall semester? Q11. Compare the peer feedback task in the spring semester and the feedback task in the fall semester. Q1 to Q7 were answered by 4-point Likert scale of 1 (not at all) to 4 (very much). The students also stated reasons of their choices for Q1, Q2, and Q8. Q9 to Q10 were open-ended questions.

\subsection{Data Analysis}

The collected data included rated scores of the pre- and post-test writing and responses to the questionnaire. The data were analyzed (1) to examine whether the students improved their writing quality throughout the semester, (2) to investigate differences between score gains of class 1 and class 2, and to explore (3) students' perceptions towards the tasks, and (4) possible correlations between the students' perceptions and the post-test scores for each aspect of writing. The quantitative data were run through SPSS 18.0 for Mac for analysis. A repeated-measures $t$-test for correlated means was conducted for the first and second points, and Spearman's non-parametric correlation analysis was used for the third and fourth points. Responses to open-ended questions in the questionnaire were analyzed qualitatively.

\section{Results}

\subsection{Writing Quality}

Sufficient inter-rater reliability was achieved between the two raters $(\alpha=.857$ for the pre-test, $\alpha=.787$ for the post-test). Therefore, the average scores by the two raters were used for analysis.

Table 2. Means of pre- and post-test total scores

\begin{tabular}{llll}
\hline & Pre-test & Post-test & Difference \\
\hline Class 1 $(n=22)$ & $53.39(9.89)$ & $58.09(10.04)$ & 4.70 \\
Class 2 $(n=22)$ & $64.02(15.22)$ & $70.89(6.98)$ & 6.87 \\
\hline
\end{tabular}

Note. Values enclosed in parentheses represent standard deviations.

Comparing the results of the pre- and post-tests as shown in Table 2, the mean total score increased by 4.70 for class 1 and 6.87 for class 2 . Although the results appear to suggest more score gains for class 2 than class 1 , the score increase was not statistically significant for class 1 as the repeated-measures $t$-test was found to be -1.86 ( $p$ $=.078, d f=21)$, while the repeated-measures $t$-test was found to be -2.62 , significant at $p=.016$. $(d f=21)$ for class 2.

\subsection{Questionnaire}

The results of the questionnaire survey were examined quantitatively and qualitatively. Questionnaire responses will be reported first by frequency distribution. The analytical results of correlation measures among responses for each question item are then reported. Table 3 summarizes students' responses to Q1 and Q2 that asked about students' perception of the usefulness of the feedback task in the fall semester (i.e., a task to review peer texts without negotiation for class 1 and a task to review one's own texts for class 2).

Table 3. Students' perceived usefulness of the feedback tasks in the fall semester in revising text and for learning about writing

\begin{tabular}{lllll}
\hline & $\begin{array}{l}\text { Q1. Was the feedback task in the fall } \\
\text { semester useful in revising your texts? }\end{array}$ & $\begin{array}{l}\text { Q2. Was the feedback task in the fall } \\
\text { semester useful for learning about writing? }\end{array}$ \\
\cline { 2 - 5 } & \multicolumn{1}{l}{ Class 1 $(n=25)$} & Class 2 $(n=26)$ & Class 1 $(n=25)$ & Class 2 $(n=26)$ \\
\hline Very useful & $5(20.0)$ & $11(42.3)$ & $11(44.0)$ & $9(34.6)$ \\
Quite useful & $15(60.0)$ & $8(30.8)$ & $13(52.0)$ & $15(57.7)$ \\
Not so useful & $5(20.0)$ & $7(27.0)$ & $1(4.0)$ & $2(7.7)$ \\
Not at all useful & 0 & 0 & 0 & 0 \\
\hline
\end{tabular}

Note. Values enclosed in parentheses represent percentages. 
The responses to these questions were significantly correlated for both class $1(r=.428, p<.01)$ and class $2(r$ $=.525, p<.01)$. These results indicate that the majority of students in both classes perceived usefulness of the tasks both in revising their texts and for learning about writing.

The students reported reasons for their choices for Q1 and Q2. For Q1, reasons stated by class $1(n=22)$ included: I have begun to read my own texts carefully so as to recognize errors and flaws by myself ( $n=9) ;$ I could refer to others' texts as a source of information or an example of errors $(n=6)$; I wish I could receive peer comments from others so that I could refer to them while revising $(n=4)$.

Reasons stated by class $2(n=24)$ included: I have begun to read my own texts carefully so as to recognize errors and flaws by myself $(n=16)$; There was a certain point when I needed feedback from others because it was difficult to know if my review was sufficient or accurate, especially at the content level $(n=9)$. As for Q2, reasons stated by class $1(n=21)$ included: My writing skills have improved $(n=11)$; I could be aware of the fact that there are certain rules in writing $(n=5)$. Reasons stated by class $2(n=22)$ included: I could be aware of a set of writing aspects, especially organization ( $n=11)$; My writing skills have improved $(n=8)$. What is noteworthy here is that not a few students understood Q2 as asking about their achievement of writing skills while the question was rather intended to ask about their metacognitive understanding of the nature of writing (academic paragraph writing) and its process.

The responses to Q3 are summarized in Table 4.

Table 4. Students' perceived effectiveness of reading peer texts in learning to write

\begin{tabular}{lll}
\hline & Q3. Is reading peer texts effective in learning to write? \\
\cline { 2 - 3 } & Class 1 $(n=25)$ & Class 2 $(n=26)$ \\
\hline Very effective & $15(60.0)$ & $12(46.2)$ \\
Quite effective & $10(40.0)$ & $13(50.0)$ \\
Not so effective & 0 & $1(3.8)$ \\
Not at all effective & 0 & 0 \\
\hline
\end{tabular}

Note. Values enclosed in parentheses represent percentages.

The results show that almost all of the students of both classes, except for one in class 2 , found reading peer texts either very effective or quite effective in learning to write.

The responses for Q4 and Q5 are summarized in Table 5.

Table 5. Students' perceived effectiveness of providing written or oral peer comments in learning to write

\begin{tabular}{lllll}
\hline & \multicolumn{2}{l}{$\begin{array}{l}\text { Q4. Is providing written peer comments } \\
\text { effective in learning to write? }\end{array}$} & $\begin{array}{l}\text { Q5. Is providing oral peer comments } \\
\text { effective in learning to write? }\end{array}$ \\
\cline { 2 - 5 } & Class 1 $(n=25)$ & Class 2 $(n=26)$ & Class 1 $(n=25)$ & Class 2 $(n=26)$ \\
\hline Very effective & $12(48.0)$ & $10(38.5)$ & $8(32.0)$ & $10(38.5)$ \\
Quite effective & $12(48.0)$ & $13(50.0)$ & $12(48.0)$ & $12(46.2)$ \\
Not so effective & $1(4.0)$ & $3(11.5)$ & $4(16.0)$ & $3(11.5)$ \\
Not at all effective & 0 & 0 & $1(4.0)$ & $1(3.8)$ \\
\hline
\end{tabular}

Note. Values enclosed in parentheses represent percentages.

The results suggest that the majority of the students considered providing both written and oral peer comments as effective. The responses to Q5 showed a significant correlation with the responses to Q2 for class $1(r=.413, p$ $<.01)$ possibly suggesting that the students were aware of the effectiveness of providing oral comments that went along with reviewing peer texts in the previous semester. 
The responses for Q6 and Q7 are summarized in Table 6.

Table 6. Students' perceived effectiveness of receiving written or oral peer comments in learning to write

\begin{tabular}{lllll}
\hline & $\begin{array}{l}\text { Q6. Is receiving written peer comments } \\
\text { effective in learning to write? }\end{array}$ & $\begin{array}{l}\text { Q7. Is receiving oral peer comments } \\
\text { effective in learning to write? }\end{array}$ \\
\cline { 2 - 5 } & Class 1 $(n=25)$ & Class 2 $(n=26)$ & Class 1 $(n=25)$ & Class 2 $(n=26)$ \\
\hline Very effective & $16(64.0)$ & $17(65.4)$ & $11(44.0)$ & $15(57.7)$ \\
Quite effective & $8(32.0)$ & $7(27.0)$ & $11(44.0)$ & $9(34.6)$ \\
Not so effective & $1(4.0)$ & $2(7.7)$ & $2(8.0)$ & $1(3.8)$ \\
Not at all effective & 0 & 0 & $1(4.0)$ & $1(3.8)$ \\
\hline
\end{tabular}

Note. Values enclosed in parentheses represent percentages.

The results suggest that the majority of the students found it effective to receive peer comments, both written and oral. For class 1, the responses to Q6 were significantly correlated with the responses to Q2 $(r=.435, p<.01)$, indicating that the students were aware of the effectiveness of reviewing peer texts along with receiving written comments. The responses to Q7 were significantly correlated with the responses to Q4 $(r=.398, p<.01)$, Q5 ( $r$ $=.839, p<.01)$, and Q6 $(r=.494, p<.01)$, suggesting that the students were aware of the equal effectiveness of the whole process of exchanging comments, both written and oral.

As for class 2, the responses to Q6 were significantly correlated with the responses to Q4 $(r=.695, p<.05)$ and Q5 $(r=.478, p<.01)$. Moreover, the responses to Q7 were significantly correlated with those for Q5 $(r=.547, p$ $<.05)$ and Q6 $(r=.440, p<.01)$. These results indicate that that the students in class 2 were also aware of the effectiveness of the whole process of exchanging comments, both written and oral.

Tables 7 and 8 summarize the results of correlational analyses of the responses to each question item for classes 1 and 2 . The question statements are paraphrased in the tables.

Table 7. Correlational results among the responses to the questionnaire for class 1

\begin{tabular}{|c|c|c|c|c|c|c|c|}
\hline & $\begin{array}{l}\text { Q1: } \\
\text { The task } \\
\text { was useful } \\
\text { in revising } \\
\text { texts }\end{array}$ & $\begin{array}{l}\text { Q2: } \\
\text { The task } \\
\text { was useful } \\
\text { for learning } \\
\text { about } \\
\text { writing }\end{array}$ & $\begin{array}{l}\text { Q3: } \\
\text { Reading } \\
\text { peer texts is } \\
\text { effective }\end{array}$ & $\begin{array}{l}\text { Q4: } \\
\text { Providing } \\
\text { written peer } \\
\text { comments is } \\
\text { effective }\end{array}$ & $\begin{array}{l}\text { Q5: } \\
\text { Providing } \\
\text { oral peer } \\
\text { comments is } \\
\text { effective }\end{array}$ & $\begin{array}{l}\text { Q6: } \\
\text { Receiving } \\
\text { written peer } \\
\text { comments is } \\
\text { effective }\end{array}$ & $\begin{array}{l}\text { Q7: } \\
\text { Receiving } \\
\text { oral peer } \\
\text { comments is } \\
\text { effective }\end{array}$ \\
\hline$Q 1$ & - & $.428 *$ & -.129 & .238 & .271 & .250 & .289 \\
\hline$Q^{2}$ & - & - & .270 & .091 & $.413^{*}$ & $.435^{*}$ & .258 \\
\hline$Q 3$ & - & - & - & .019 & .012 & -.061 & -.106 \\
\hline$Q^{4}$ & - & - & - & - & .126 & .343 & $.398^{*}$ \\
\hline$Q 5$ & - & - & - & - & - & .268 & $.839 * *$ \\
\hline Q6 & - & - & - & - & - & - & $.494 *$ \\
\hline
\end{tabular}

Note. ${ }^{*} \mathrm{p}<.05, * * \mathrm{p}<.01$. 
Table 8. Correlational results among the responses to the questionnaire for class 2

\begin{tabular}{|c|c|c|c|c|c|c|c|}
\hline & $\begin{array}{l}\text { Q1: } \\
\text { The task } \\
\text { was useful } \\
\text { in revising } \\
\text { texts }\end{array}$ & $\begin{array}{l}\text { Q2: } \\
\text { The task } \\
\text { was useful } \\
\text { for learning } \\
\text { about } \\
\text { writing }\end{array}$ & $\begin{array}{l}\text { Q3: } \\
\text { Reading } \\
\text { peer texts is } \\
\text { effective }\end{array}$ & $\begin{array}{l}\text { Q4: } \\
\text { Providing } \\
\text { written peer } \\
\text { comments is } \\
\text { effective }\end{array}$ & $\begin{array}{l}\text { Q5: } \\
\text { Providing } \\
\text { oral peer } \\
\text { comments is } \\
\text { effective }\end{array}$ & $\begin{array}{l}\text { Q6: } \\
\text { Receiving } \\
\text { written peer } \\
\text { comments is } \\
\text { effective }\end{array}$ & $\begin{array}{l}\text { Q7: } \\
\text { Receiving } \\
\text { oral peer } \\
\text { comments is } \\
\text { effective }\end{array}$ \\
\hline$Q 1$ & - & $.525^{*}$ & -.131 & -.016 & .076 & .133 & -.024 \\
\hline$Q 2$ & - & - & -.006 & .119 & .137 & .208 & .280 \\
\hline$Q 3$ & - & - & - & .225 & -.005 & .066 & -.100 \\
\hline$Q 4$ & - & - & - & - & .290 & $.695 * *$ & .156 \\
\hline$Q 5$ & - & - & - & - & - & $.478^{*}$ & $.547 * *$ \\
\hline Q6 & - & - & - & - & - & - & $.440 *$ \\
\hline
\end{tabular}

Note. $* \mathrm{p}<.05, * * \mathrm{p}<.01$.

With regard to Q8 (Which was more effective for you, the peer feedback task in the spring semester or the feedback task in the fall semester?), for class $1(n=24), 20$ students $(83.3 \%)$ preferred a standard type of peer feedback, such as that conducted in the spring semester while the remaining four students $(16.7 \%)$ preferred the feedback task focusing on reviewing peer texts without negotiation. The reasons stated for choosing a standard type of peer feedback task basically pointed out that peer comments were given back to the writers $(n=4)$. On the other hand, the reasons for preferring the feedback task in the fall semester included: The task demanded more thinking $(n=6)$; I could read more peer texts $(n=4)$; I could spare more time on the task without peer negotiation $(n=1)$.

For class $2(n=26), 15$ students $(57.7 \%)$ preferred a standard type of feedback such as that conducted in the spring semester while 11 students $(42.3 \%)$ preferred the feedback task focusing on reviewing their own texts. The reasons stated for choosing a standard type of peer feedback basically pointed out that it was more helpful when peers reviewed their texts and gave comments $(n=11)$. One student also pointed out that a standard type of peer feedback was useful because it provided an opportunity to read peer texts. On the other hand, the reasons for preferring the feedback task in the fall semester included: I could learn to review my texts in detail $(n=4)$; It was free from the pressure of reviewing others' texts $(n=1)$; I could give meaningful feedback to my own texts than could peers $(n=1)$.

The responses to open-ended questions of Q9, Q10, and Q11 will be summarized below. For Q9 that asked about perceived advantages of the feedback task in the fall semester, responses by class 1 included: Reviewing many peer texts itself was useful $(n=10)$; I could learn the writing process from outline to final draft $(n=4)$; The detailed task sheets were useful $(n=3)$; Enough time was given to review peer texts without negotiation $(n=2)$; The writing cycle was fast so we could write many paragraphs $(n=1)$. Responses by class 2 included: My self-revision skills have improved $(n=19)$; I could learn the revision process by working on the task sheets $(n=3)$; It was efficient and saved time not to include negotiation $(n=1)$; I could know the level of my writing skills $(n=1)$.

For Q10 that asked about difficulties in working on the feedback task during the fall semester, responses by class 1 included: It was difficult to suggest further development of ideas $(n=12)$ : It was difficult to revise my own texts without receiving peer comments $(n=5)$; It was difficult to detect errors or flaws in peer texts $(n=1)$; It was difficult to understand the writers' intentions when reading the texts without negotiation $(n=1)$. Responses by class 2 included: It was difficult to detect and correct errors in my own texts $(n=15)$; It was difficult to revise my texts for the sake of readers because no peer comments were given $(n=7)$.

Finally, for Q11 that asked students to compare feedback tasks during the spring semester (a standard type of peer feedback) and the fall semester (reviewing peer texts without negotiation in class 1, reviewing one's own texts in class 2), responses by class 1 included: It would have been easier to revise my texts if the peer comments were given back as in the spring semester $(n=7)$; It was good to review peer texts in detail with enough time in the fall semester $(n=5)$. Responses by class 2 included: It would have been most effective if the two tasks were 
combined in order to thoroughly review peer texts and one's own texts $(n=10)$; I became more responsible for and could concentrate on revising my texts in the fall semester $(n=7)$; Peer feedback during the spring semester was more helpful and fun $(n=4)$; I disliked the pressure to review others' texts in the spring semester $(n=1)$.

\subsection{Writng Quality and Student Perception}

The correlation measure was calculated between the post-test scores for each aspect of writing and responses for Q1 through Q7. The descriptive scores of the post-test are shown in Table 9.

Table 9. Post-test writing descriptive scores for each aspect of writing

\begin{tabular}{lll}
\hline & Class $1(n=22)$ & Class 2 $(n=22)$ \\
\cline { 2 - 3 } & Post-test & Post-test \\
\hline Content & $19.43(3.04)$ & $21.66(.48)$ \\
Organization & $12.57(2.22)$ & $15.18(.44)$ \\
Vocabulary & $11.30(2.19)$ & $14.23(.40)$ \\
Language use & $11.84(3.18)$ & $16.32(.44)$ \\
Mechanics & $2.93(.47)$ & $3.50(.07)$ \\
\hline
\end{tabular}

Note. Values enclosed in parentheses represent standard deviations.

For class 1, the responses to Q3 (Is reading peer texts effective for learning to write?) were significantly correlated with their scores of four aspects of writing: content $(r=.447, p<.01)$, organization $(r=.538, p<.01)$, vocabulary $(r=.480, p<.01)$, and language use $(r=.499, p<.01)$. These results appear to indicate that reading peer texts appealed as an effective task. On the other hand, the responses to Q5 (Is providing oral peer comments effective for learning to write?) resulted in significantly negative correlations with the scores of content ( $r=$ $-.590, p<.05)$ and organization $(r=-.474, p<.01)$ as well as the responses of Q7 (Is receiving oral peer comments effective for learning to write?) which showed significantly negative correlations with the scores of content $(r=-.599, p<.05)$, organization $(r=.463, p<.01)$, and mechanics $(r=-.465, p<.01)$. Given that most students responded to Q5 and Q7 that providing and receiving oral peer comments was either very effective or quite effective despite their post-test scores, the statistical results could mean that oral negotiation experienced in the previous semester appealed to the students in class 1 as effective, possibly even better than exchanging written peer comments. There was no significant correlation between the scores for each aspect of writing and questionnaire responses for class 2 .

\section{Discussion}

The purpose of the present study was to examine which feedback task was more beneficial to improving learner writing, to review peer texts or one's own texts. The answer to the first research question of whether students who review peer texts improve their writing quality more than those who only review their own texts is negative. From the raw score results, it appeared that the total score increased from pre- to post-test for both classes, and the students who focused on reviewing their own texts had greater total score gains than did the students who focused on reviewing peer texts. However, the difference in the score gains between the two groups was not affirmatively significant because a significant gain was observed only with the students in class 2 . It is also interesting to compare the score results of the pre- and post-tests for class 2 in terms of standard deviation. The value of standard deviation decreased from 15.22 for the pre-test average score to 6.98 for the post-test average score indicating that more students scored closer to the average score for the post-test than for the pre-test. This may suggest that the task of reviewing one's own text might have had a stronger impact on lower level students raising their scores to correspond more closely to the higher level students at the post-test. On the other hand, other factors might have influenced this effect including among those are, using detailed feedback task sheets, receiving occasional teacher comments, and other aspects of the writing instruction they received over the semester.

The second research question asked how students perceived two types of feedback task (reviewing peer texts without exchanging comments and reviewing only one's own text) compared with a standard type of peer feedback task (reviewing peer texts with comment exchange and oral negotiation). Students in class 1 who worked on a feedback task to review peer texts without negotiation appreciated the task because it enabled them 
to review many more peer texts in a more analytical manner than they did by a standard type of peer feedback. However, they still expressed the need to receive peer comments, as they did in the previous semester. In fact, when they were asked which task they preferred, a majority chose the standard type of peer feedback. Students in class 2 who reviewed only their own texts also appreciated the given task because they could concentrate on reviewing their texts analytically and thoroughly. However, when they were asked which task they preferred, a majority chose the standard type of peer feedback. The students in both classes expressed their needs for the missing element experienced in the standard type, to receive peer comments, though the need for reading peer texts was not really mentioned by the students in class 2 .

Interestingly, when the students were asked about the effectiveness of providing and receiving written or oral comments, they tended to report the activities to be almost equally effective. However, when they expressed difficulty of the tasks during the fall semester compared with a standard type of peer feedback, the expressed needs were related mostly to receiving written peer comments. The students' less attended needs for oral peer comments might suggest that peer negotiation is not always a necessary component in a procedure of peer feedback. In fact, some students were aware of the efficiency of not including peer negotiation in the procedure saying that without negotiation, it ensured enough time to engage in detailed reviews.

To summarize, the students' writing quality, which was assessed by pre- and post-test timed essays, revealed a statistically significant improvement for those who reviewed only their own texts. The results could support an assertion that reviewing peer texts does not ensure more benefits than reviewing only one's own texts, but rather, reviewing one's own texts could be a sufficient if not more effective feedback task for improving writing quality. On the other hand, according to the results of the questionnaire survey, the students basically felt the need to receive peer comments, especially in written form. However, if reviewing one's own texts sufficiently improves writing quality, then do students really need to use peer comments in a way that improves writing quality? Mixed results have been reported that peer comments were not well utilized in revision (Connor \& Asenavage, 1994) and that peer comments were utilized very much in revision, especially when they received training for peer feedback (Nelson \& Murphy, 1993; Paulus, 1999). Nelson \& Murphy (1993) reported that the majority of revisions that used peer comments were given in interactive and collaborative peer feedback sessions, suggesting the significance of both written comments and proper peer negotiation.

As mentioned earlier, the rationale of peer feedback is explained by the Vygotsky's $(1978,1986,1987)$ notion of ZPD where cognitive development occurs through scaffolding with more experienced others or through collective scaffolding with peers. Therefore, the interaction with others is at the center of peer feedback. However, the participants in the present study did not engage in peer negotiation but focused on reviewing peer texts. The results revealed that learners fell behind those who reviewed their own texts in terms of score gains between pre- and post-tests. This finding could indicate that peer negotiation adds supplemental benefits to the peer feedback process, even if learners are not fully aware of the need for it. It is still worth examining the comparative significance of reviewing peer texts, exchanging peer comments, and negotiating with peers.

The major limitation of the present study was that two different types of feedback tasks were conducted with two groups of students at two different proficiency levels. The combinations of a task and a class could have had effects on the students' performances, and it would have been optimal for a study to divide students within one class into a treatment group and a control group. However, the author avoided doing so because, as the study was conducted in the fall semester of a yearlong course that starts with the spring semester, the students did not have another semester to receive the other treatment.

\section{Conclusion}

This study examined the comparative benefits of reviewing peer texts and one's own texts. It is one of the few studies that investigated the effects of peer feedback on the reviewers' own writing using qualitative data. Among various cognitive activities involved in peer feedback, the study focused on the activity of reviewing peer texts, as it is at the center of a reviewer's role, a cognitive activity that has been asserted to develop critical evaluation and self-revision skills. Peer negotiation, a typical component of peer feedback, was not included in the procedure so as to focus on differences in outcomes between reviewing peer texts and reviewing one's own texts. Results indicated that students who reviewed their own texts showed significant gains between pre- and post-tests while those who reviewed peer texts did not show significant gains. These results may indicate that reviewing one's own texts is sufficient to develop writing skills, with or without reviewing peer texts. In other words, sparing time on reviewing one's own texts without reviewing peer texts can be beneficial. Moreover, a possibility was raised that interacting with peers is a crucial factor for the peer feedback process to be fully beneficial. Yet it should not be ignored that the students preferred a standard type of peer feedback where 
students read each other's texts and exchange comments. The students in both groups basically wanted to receive peer comments, especially in written form. It is unknown how useful peer comments actually are for revision among these particular students, and it is also possible that the students merely felt vague, implicit effectiveness in exchanging comments. Besides its effects on writing quality, the effects of taking the reviewer's role in peer feedback require further examination. In other words, the effects of giving written or oral peer comments and those of peer negotiation on the quality of one's own texts warrant further examination.

The present study sorted out a process of peer feedback in terms of cognitive activities. Among four cognitive activities involved in peer feedback that were presented in Table 1, reviewing peer texts and providing self-feedback were focused upon in the study. Utilizing peer comments and negotiation in peer discussion have been studied previously (Carson \& Nelson, 1996; Connor \& Asenavage, 1994; Kamimura, 2006; Lockhart \& Ng, 1995a, 1995b; Mangelsdorf \& Schlumberger, 1992; Mendonça \& Johnson, 1994; Min, 2005, 2006, 2008, Nelson \& Murphy, 1993; Villamil \& De Guerrero, 1996), yet further investigation is still worthwhile. This study also attempted to set forth a new definition of peer feedback as a collaborative learning task. It is hoped that practitioners, including students, understand peer feedback as a task, rather than merely a type of feedback, so that researchers can examine benefits of peer feedback for learners as active agents both as reviewer and writer, and so that both teachers and students can make a clear distinction between peer feedback and teacher feedback.

\section{References}

Anton, M., \& DiCamilla, F. (1998). Sociocognitive functions of L1 collaborative interaction in the L2 classroom. Canadian Modern Language Journal, 54, 314-342. http://dx.doi.org/10.3138/cmlr.54.3.314

Berg, E. C. (1999). The effects of trained peer response on ESL students' revision types and writing quality. Journal of Second Language Writing, 8(3), 215-241. http://dx.doi.org/10.1016/S1060-3743(99)80115-5

Bruffee, K. A. (1984). Collaborative learning and the "conversation of mankind." College English, 46(7), 635-652. http://dx.doi.org/10.2307/376924

Carson, J. G., \& Nelson, G. L. (1994). Writing groups: Cross-cultural issues. Journal of Second Language Writing, 3(1), 17-30. http://dx.doi.org/10.1016/1060-3743(94)90003-5

Carson, J. G., \& Nelson, G. L. (1996). Chinese students' perceptions of ESL peer response group interaction. Journal of Second Language Writing, 5, 1-19. http://dx.doi.org/10.1016/S1060-3743(96)90012-0

Connor, U., \& Asenavage, K. (1994). Peer response groups in ESL writing classes: How much impact on revision? Journal of Second Language Writing, 3(3), 257-276. http://dx.doi.org/10.1016/1060-3743(94)90019-1

De Guerrero, M. C. M., \& Villamil, O. S. (1994). Social-cognitive dimensions of interactions in L2 peer revision. The Modern Language Journal, 78, 484-496. http://dx.doi.org/10.2307/328586

De Guerrero, M. C. M., \& Villamil, O. S. (2000). Activating the ZPD: Mutual scaffolding in L2 peer revision. The Modern Language Journal, 84(1), 51-68. http://dx.doi.org/10.1111/0026-7902.00052

Diab, N. M. (2010a). Effects of peer versus self-editing on students' revision of language errors in revised drafts. System, 38, 85-95. http://dx.doi.org/10.1016/j.system.2009.12.008

Diab, N. M. (2010b). Peer-editing versus self-editing in the ESL classroom. Proceedings from ISPR 2010: The 2nd International Symposium on Peer Reviewing. Retrieved from http://www.iiis.org/CDs2010/CD2010SCI/ISPR_2010/PapersPdf/VA909UP.pdf

Diab, N. M. (2011). Assessing the relationship between different types of student feedback and the quality of revised writing. Assessing Writing, 16, 274-292. http://dx.doi.org/10.1016/j.asw.2011.08.001

DiCamilla, F., \& Anton, M. (1997). Repetition in the collaborative discourse of L2 learners: A Vygotskian perspective. Canadian Modern Language Review, 53, 609-633.

Donato, R. (1994). Collective scaffolding in second language learning. In J. P. Lantolf, \& G. Appel (Eds.), Vygotskian approaches to second language research (pp. 33-56). Norwood, NJ: Ablex.

Ferris, D. R. (2003). Response to Student Writing: Implications for Second Language Students. Mahwah, NJ: Lawrence Erlbaum.

Hedgcock, J., \& Lefkowitz, N. (1992). Collaborative oral/aural revision in foreign language instruction. Journal of Second Language Writing, 1(3), 255-276. http://dx.doi.org/10.1016/1060-3743(92)90006-B

Hogue, A. (2008). First Steps in Academic Writing Level 2. Harlow, England: Pearson Longman. 
Jacobs, H. L., Hartfiel, V. F., Hughly, J. B., Wormuth, D. R., \& Zinkgraf, S. A. (1981). Testing ESL Composition: A practical approach. Rowly, MA: Newbury House Publishers.

Kamimura, T. (2006). Effects of peer feedback on EFL student writers at different levels of English proficiency: A Japanese context. TESL Canada Journal, 23, 12-39.

Keh, C. L. (1990). Feedback in the writing process: a model and methods for implementation. ELT Journal, 44(4), 294-304. http://dx.doi.org/10.1093/elt/44.4.294

Liu, J., \& Hansen, J. G. (2005). Peer response in second language writing classrooms. Michigan: The University of Michigan Press.

Lockhart, C., \& Ng, P. (1995a). Analyzing talk in ESL peer response groups: Stances, functions, and content. Language Learning, 45, 605-655. http://dx.doi.org/10.1111/j.1467-1770.1995.tb00456.x

Lockhart, C., \& Ng, P. (1995b). Student stances during peer response in writing. In M. L. Tickoo (Ed.), Reading and writing: Theory into practice (pp. 118-132). SEAMEO Regional Language Centre: RELC.

Lundstorm, K., \& Baker, W. (2009). To give is better than to receive: The benefits of peer review to the reviewer's own writing. Journal of Second Language Writing, 18(1), 30-43. http://dx.doi.org/10.1016/j.jslw.2008.06.002

Mangelsdorf, K. (1992). Peer reviews in the ESL composition classroom: What do the students think? ELT Journal, 46, 274-284. http://dx.doi.org/10.1093/elt/46.3.274

Mangelsdorf, K., \& Schlumberger, A. L. (1992). ESL student response stances in a peer-review task. Journal of Second Language Writing, 1, 235-254. http://dx.doi.org/10.1016/1060-3743(92)90005-A

Mendonça, C., \& Johnson, K. (1994). Peer review negotiations: Revision activities in ESL writing instruction. TESOL Quarterly, 28, 745-769. http://dx.doi.org/10.2307/3587558

Min, H. (2005). Training students to become successful peer reviewers. System, 33, 293-308. http://dx.doi.org/10.1016/j.system.2004.11.003

Min, H. (2006). The effects of trained peer review on EFL students' revision types and writing quality. Journal of Second Language Writing, 15, 118-141. http://dx.doi.org/10.1016/j.jslw.2006.01.003

Min, H. (2008). Reviewers' stances and writer perceptions in EFL peer review training. English for Specific Purposes, 27, 285-305. http://dx.doi.org/10.1016/j.esp.2008.02.002

Mittan, R. (1989). The peer review process: Harnessing students' communicative power. In D. M. Johnson, \& D. H. Roen (Eds.), Richness in writing: Empowering ESL students (pp. 207-219). New York: Longman.

Nakanishi, C. (2008). The effects of trained self-feedback on revision. JACET Journal, 47, 35-49.

Nelson, G., \& Murphy, J. (1993). Peer response groups: Do L2 writers use peer comments in revising their drafts? TESOL Quarterly, 27(1), 135-141. http://dx.doi.org/10.2307/3586965

Paulus, T. M. (1999). The effect of peer and teacher feedback on student writing. Journal of Second Language Writing, 8, 265-289. http://dx.doi.org/10.1016/S1060-3743(99)80117-9

Raimes, A. (1985). What unskilled ESL students do as they write: A classroom study of composing. TESOL Quarterly, 19(2), 229-258. http://dx.doi.org/10.2307/3586828

Rollinson, P. (2005). Using peer feedback in the ESL writing class. ELT Journal, 59(1), 23-30. http://dx.doi.org/10.1093/elt/cci003

Tsui, A. B. M., \& Ng, M. (2000). Do secondary L2 writers benefit from peer comments? Journal of Second Language Writing, 9, 147-170. http://dx.doi.org/10.1016/S1060-3743(00)00022-9

Vygotsky, L. (1978). Mind in society: The development of higher psychological processes. Cambridge, MA: Harvard University Press.

Vygotsky, L. (1986). Thought and language (A. Kozulin, Trans.). Cambridge, MA: MIT Press.

Vygotsky, L. (1987). The collected works of L. S. Vygotsky. (R. W. Rieber, \& A. S. Carton, Trans.). New York: Plenum Press.

Villamil, O. S., \& De Guerrero, M. C. M., (1996). Peer revision in the L2 classroom: Social-cognitive activities, mediating strategies, and aspects of social behavior. Journal of Second Language Writing, 5(1), 51-76. http://dx.doi.org/10.1016/S1060-3743(96)90015-6 
Villamil, O. A., \& De Guerrero, M. C. M. (1998). Assessing the impact of peer revision on L2 Writing. Applied Linguistics, 19(4), 491-514. http://dx.doi.org/10.1093/applin/19.4.491

Wood, D., Bruner, J. S., \& Ross, G. (1976). The role of tutoring in problem solving. Journal of Child Psychology and Psychiatry, 17, 89-100. http://dx.doi.org/10.1111/j.1469-7610.1976.tb00381.x

Zamel, V. (1983). The composing processes of advanced ESL students: six case studies. TESOL Quarterly, 17(2), 165-187. http://dx.doi.org/10.2307/3586647

Zamel, V. (1985). Responding to student writing. TESOL Quarterly, 19(1), 79-101. http://dx.doi.org/10.2307/3586773

\section{Appendix A}

\section{Writing Topics}

\begin{tabular}{|c|c|}
\hline Type of paragraph & Writing topic \\
\hline \multirow[t]{7}{*}{ Reason } & 1. $\quad$ Reasons to study at my University \\
\hline & 2. Reasons to major in ... \\
\hline & 3. Reasons to live near campus \\
\hline & 4. Reasons not live near campus \\
\hline & 5. Reasons to learn ... \\
\hline & 6. Reasons to ... \\
\hline & 7. Reasons not to ... \\
\hline \multirow[t]{4}{*}{ Opinion } & $\begin{array}{l}\text { 1. Should people avoid using cell phones in public places? Use specific reasons and } \\
\text { examples to explain your answer. }\end{array}$ \\
\hline & $\begin{array}{l}\text { 2. Is capital punishment necessary? Use specific reasons and examples to explain } \\
\text { your answer. }\end{array}$ \\
\hline & $\begin{array}{l}\text { 3. In your opinion, what is the most important characteristic (for example, honesty, } \\
\text { intelligence, a sense of humor) that a person can have to be successful in life? } \\
\text { Use specific reasons and examples to explain your answer. When you write your } \\
\text { answer, you are not limited to the examples listed in the prompt. }\end{array}$ \\
\hline & 4. Your topic \\
\hline Comparison & Free topic \\
\hline Contrast & Free topic \\
\hline
\end{tabular}




\section{Appendix B}

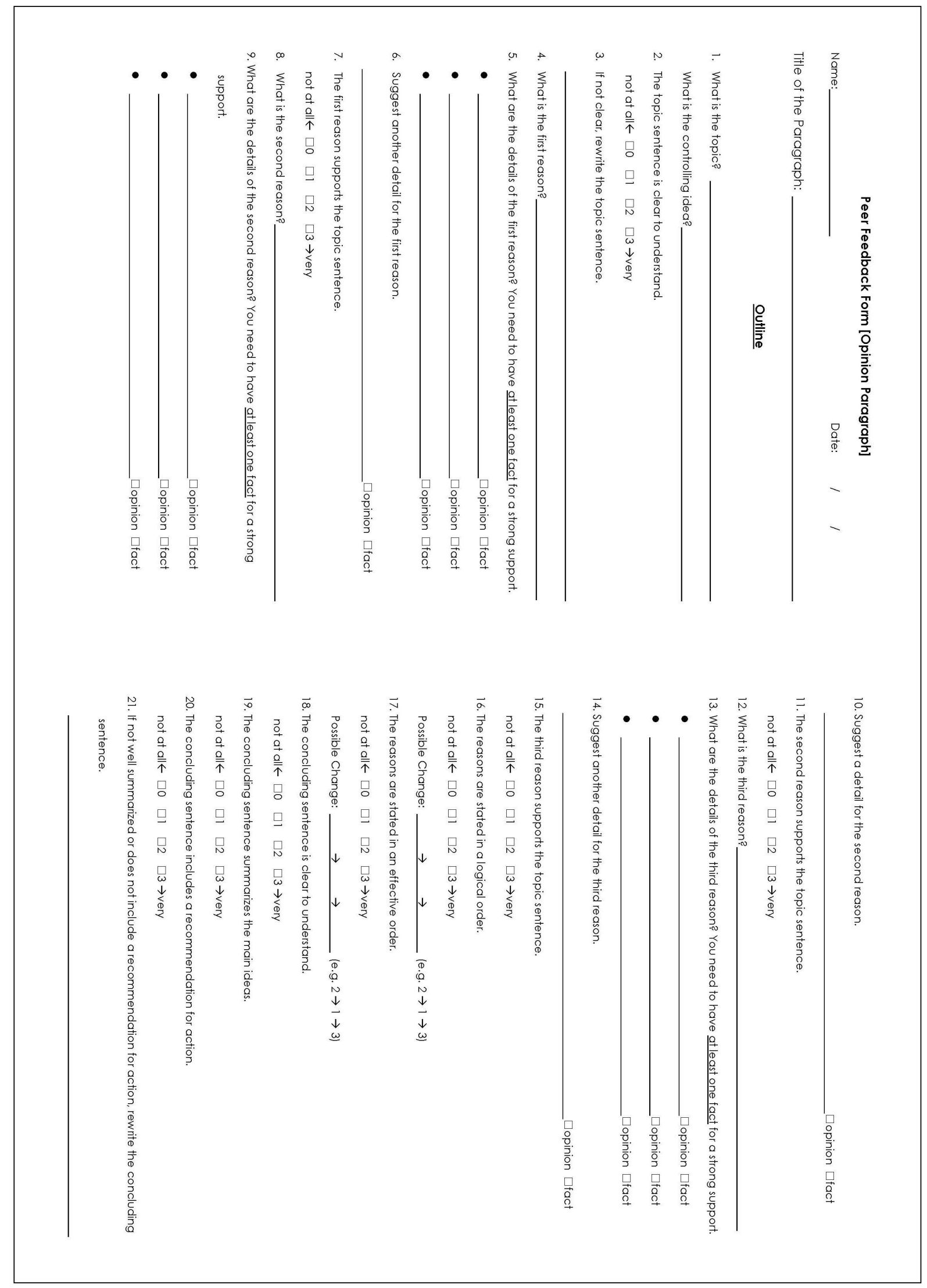




\section{Appendix C}

\section{A Task Sheet for Class 2}

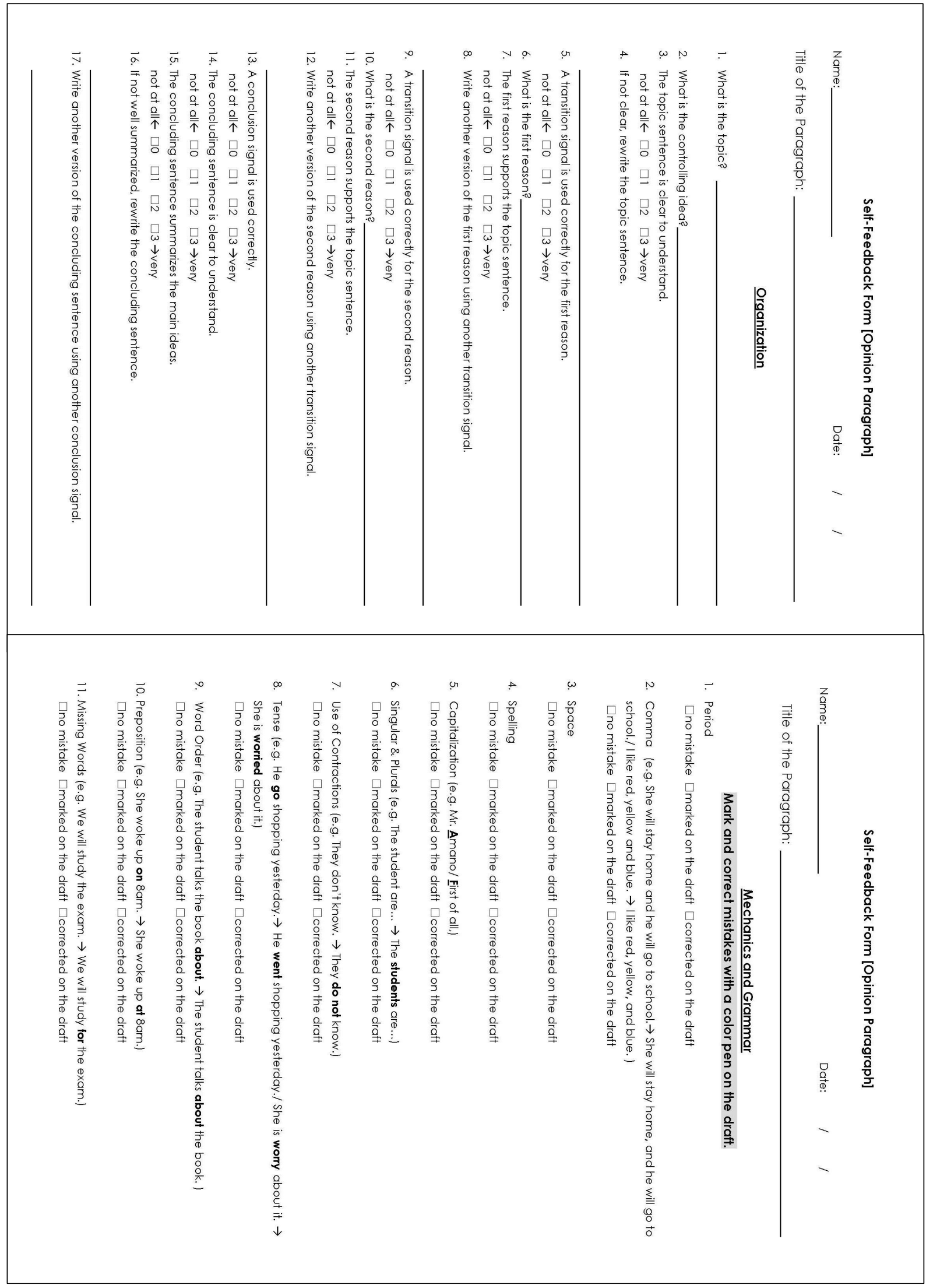




\section{Copyrights}

Copyright for this article is retained by the author(s), with first publication rights granted to the journal.

This is an open-access article distributed under the terms and conditions of the Creative Commons Attribution license (http://creativecommons.org/licenses/by/3.0/). 